\title{
Does gender role influence the pattern of internet and computer use among physiotherapy undergraduates?
}

\author{
Jayalath, L., Samaranayake, D.
}

\begin{abstract}
Gender roles affect some components of life and whether this difference persist in using advanced technologies such as computers and internet is unclear. Aim of this study was to compare the computer and internet using patterns among male and female physiotherapy undergraduates. Methods: Out of the registered physiotherapy undergraduates, 92 participated in the study with a response rate of $80 \%$. A pre-tested self-administered questionnaire was used to collect data from students in first to final academic years. Data analysis was done using SPSS version 20.

Results: Out of participants, $37 \%(n=34)$ were males and age ranged from 19 to 26 years. Majority of $95.7 \%(n=88)$ participants owns a computer and $64.1 \%(n=59)$ mainly use it for entertainment. Females tend to seek more formal learning computer classes compared to males. Majority of study participants spend more than 8 hours per week to go online and values were $29.4 \%(n=10)$ for males and $25.9 \%$ $(n=15)$ for females.

Conclusion: A significant relationship was seen between gender and formal learning classes for computers. Usage time and purposes did not show any difference among genders. Internet was used mainly for entertainment and secondly for social communication in both genders.
\end{abstract}

Keywords: computer literacy, internet, undergraduates, students

\section{Background}

In the past few decades, with the advancement of telecommunication, the use of internet and computers has increased rapidly (Ajuwon, 2003; Bubric and Hedge, 2016; Internet society, 2019; Weiser 2000). According to the internet usage statistics, the number of internet users in 2019 was estimated as 4.5 billion and was $58.7 \%$ of the total world population (Internet society 2019). Highest ratio between computer users and country's total population was found in North America of $94.6 \%$ and second highest was $87.2 \%$ in Europe. Highest internet users were found in Asia of $50.3 \%$, in Europe of $15.9 \%$ and in Africa of $11.5 \%$ from the total users around the World (Internet society 2019).

Internet and computer use within Sri Lanka is rapidly increasing. Household computer use in

University of Colombo, Sri Lanka

Corresponding author address: Lakshmi R. Jayalath, Lecturer, Department of Allied Health Sciences, Faculty of Medicine, University of Colombo. PO Box 25, Kynsey Road, Colombo 8 Sri Lanka

lakshmi@med.cmb.ac.lk
Sri Lanka has surged from $22.5 \%$ in 2016 up to $22.9 \%$ in 2018 , which has extended beyond desktops and added up laptops to this number. Out of the 2018 computer users within the country, $39.5 \%$ was spread in urban areas, $20.3 \%$ in rural and $4.9 \%$ in estate sector (Department of Census and Statistics, 2018). The number of people who can use a computer independently, which is defined as the computer literacy, was $27.5 \%$ according to 2018 statistics in Sri Lanka. However, the highest of these literates were in urban areas of the country and were about $38.4 \%$ (Department of Census and Statistics, 2018). Within Sri Lanka, there is a persisting discrepancy of computer literacy, and factors such as gender and living area are more likely to contribute towards it. Males compared to females, and urban western province compared to other parts of the country seem to have a high literacy rate (Department of Census and Statistics, 2018). Despite of these discrepancies, there is an increase in computer use within the country and around the world, due to many advantages the computer and internet offer for its users. 
Some reasons behind the popularity of internet are instant access to unlimited information (Ajuwon 2003), rapid communication via email, whatsapp, social engagement via Facebook, Instagram and diverse range of pleasure activities such as online gaming (Lee et al., 2017; Wan and Chiou 2006). All sectors including higher education and health have been caught in these rapid changes in technology and internet use (Ranasinghe et al., 2012; Thanuskodi, 2016; Unnikrishnan et al., 2008). Use of these information systems in different professions, especially in medicine and other health care services, has improved the quality of patient care by bringing evidencebased treatment information to the tip of the finger (Unnikrishnan et al 2008). With the increase in popularity, the purposes have changed from basic use to multipurpose use and it is important to identify these differences in undergraduates because they will be the future professionals in health sector (Thanuskodi, 2016). Male and female undergraduate students have different preferences and therefore if that affects the use of these technologies is a question which needs to be answered.

Gender difference seems to exist in many areas of life such as mental health, exercise attitudes and cognition. A study by Lee et al. (2020) showed that in males, mental health attitudes were significantly lower than females in same age group and was associated with social support, depression levels and being married. They further stated that increased mental health literacy had more positive mental health outcomes in both genders. Another study done in Taiwan reported that females aged between $40-64$ tend to exercise regularly and think that spending money on exercise is worthwhile (Mao, Hsu, Lee, 2020). Another study from India reported that cognitive scores were reduced in females compared to males after confounding factors such as education, height, cast, being married and physical health status were matched. They concluded that females can be a disadvantaged group in cognitive health compared to their counterparts (Singh, Jasilionis, Oksuzyan, 2018). A common assumption is that females are more anxious regarding the use of new technology and are slower in adjusting to them compared to males. This has led to many research studies, which highlight several gender differences in the use of information technology. A study done in college students has shown that females use internet more often for communication as compared males, and males tend to use it for information gathering and entertainment
(Ajuwon, 2003). Several studies discussed the differences in computer cognition among genders. Men use more email and chat rooms than females and are more active in computer games (Lee et al., 2019). Furthermore, they seem to be more confident in their computer skills than females ( $\mathrm{Li}$ and Kirkup, 2007; Weiser, 2000; Jones, 2002)

Physiotherapy undergraduates are a group who get through a competitive barrier examination to enter the University and look forward to becoming health care professionals. Admission statistics indicate that high number of females get qualified for university admission compared to males in Sri Lanka each year. Furthermore, these qualifying students belong to different geological areas of the country which can further promote discrepancies in computer and internet use (Statistical Reports, University Grants Commission, 2018). If a gender difference exists in using computers and internet, it can affect their professional achievements and subsequently for patient care. Therefore, it will be necessary to take measures to minimize these discrepancies early in their careers. This study therefore aimed to identify the current pattern of computer and internet usage among the undergraduates and any relationship between genders.

\section{Methods}

Participants aged between $20-35$ years and registered physiotherapy undergraduates in their $1^{\text {st }}$ year to final year (4 $4^{\text {th }}$ year) were selected for the study. Participants who fulfilled the inclusion exclusion criteria were recruited using convenient sampling. Students who are registered in the BSc physiotherapy course and in their first to final years were included in the study. Students who were absent from their studies or on medical / long term leave during data collection were excluded from the study. Sample size was not calculated, as the entire population of registered physiotherapy undergraduate students, was included in the study. The study was approved by the Ethics Review Committee of the Faculty of Medicine, University of Colombo, and permission was obtained from the Dean and the coordinator of the programme. Written informed consent was obtained from all participants after explaining the study objectives, methods and the opportunity was given to withdraw from the study at any time if they wanted to do so. 
Data were collected at a convenient time for the participants and was administered individually in a secure place to ensure confidentiality. The collected data were then entered to a computer, to which only the principal investigator had access. The sheets were stored under lock and key after the data collection.

\begin{abstract}
Questionnaire
Data was collected using a pre-tested semi structured questionnaire regarding their computer and internet use. This selfadministered questionnaire was developed in English with items on socio-demographic characteristics, their computer and internet use. This questionnaire was developed using existing literature (Thanuskodi,2016; Unnikrishnan et al., 2008) and discussions with the subject experts. It was then pre-tested in a group of B.Sc. Physiotherapy graduates and was modified accordingly. Significance in gender preference was assessed in computer and internet use under the categories of ownership, access, purposes, previous experience and time spent on usage.
\end{abstract}

Statistical analysis was conducted using SPSS version 20 software package. Standard descriptive methods were used to analyse baseline characteristics and computer and internet usage. Chi square test was used to identify a relationship between gender and preference of computer and internet use.

\section{Results}

Baseline characteristics

Ninety-two students out of total 115 registered students from all academic years participated in this study with the respondent rate of $80 \%$. Out of the study participants, 37\% $(n=34)$ were males and majority of them were in age group between 19 to 26 years, with only two participants of higher age group. Majority of the students $(n=81.88 \%)$ were Buddhists, 6.5\% $(n=6)$ Catholic and remaining Muslims, with one from abroad. Previous employment before entering the University was identified as a key factor in gaining experience about computer and internet use because many of employments will either fully or partially be based on computer work. In the study sample, $21.7 \%(n=20)$ had previous occupations before enrolling to the University. Out of which, 4.3\% $(n=4)$ are still engaged in part time work. Out of the participants engaged in previous employment, $70 \%(n=14)$ had used computers with or without internet as a part of their work.

Pattern of computer use

Majority of $95.7 \% \quad(n=88)$ own a computer (desktop /laptop) and the remaining have access to one. Out of males, $91.17 \%(n=31)$ and out of females $64.8 \% \quad(n=57)$ own a computer. All participants used computers for many reasons (Table 1 ). Both genders showed similar pattern of using computers with the first and commonest reason being for entertainment, second for studies and third for finding new information (Table 1). Out of the participants, $73.9 \% \quad(n=68)$ had learned computers in formal methods. From these, $81.03 \%(n=47)$ females and $61.76 \%(n=21)$ males had taken some sort of learning. However, females tended to seek significantly high number of computer classes compared to males $(p=0.042)$. Places of learning varied from private classes to school and online mode (Table 1).

When discussing the purposes of computer use in two genders, $61.76 \%(n=21)$ of males and $65.51 \%(n=38)$ of females used it for entertainment. Second commonest reason was for studies. Out of females, 53.44\% $(n=31)$ and out of males, $38.23 \%(n=13)$ used computers for education. Percentages of other purposes are shown in Table 1. In this study sample, $82.35 \%(n=28)$ of males and $93.1 \% \quad(n=54)$ females used computers at their home or hostels. Out of the participants, $60.86 \%(n=56)$ spent less than 3 hours per day on computers and this was $70.58 \% \quad(n=24)$ in males and $55.17 \%(n=32)$ in females. 
Table 1: Pattern of computer use in each gender of the study sample

\begin{tabular}{|c|c|c|c|c|c|c|c|c|}
\hline \multirow[t]{2}{*}{ Characteristics } & & \multicolumn{2}{|c|}{ Males $(n=34)$} & \multicolumn{2}{|c|}{ Females $(n=58)$} & \multicolumn{2}{|c|}{ Total $(n=92)$} & \multirow{2}{*}{$\begin{array}{l}\text { Significa } \\
\text { nce } \\
\mathbf{P}=\end{array}$} \\
\hline & & $\mathbf{N}$ & $\%$ & $\mathbf{N}$ & $\%$ & $\mathbf{N}$ & $\%$ & \\
\hline Computer use & Owns a computer & 31 & $91.17 \%$ & 57 & $64.8 \%$ & 88 & $95.7 \%$ & NS \\
\hline \multirow{5}{*}{ Purpose* } & Entertainment & 21 & $61.76 \%$ & 38 & $65.51 \%$ & 59 & $64.1 \%$ & \\
\hline & General information & 12 & $35.29 \%$ & 20 & $34.48 \%$ & 32 & $34.8 \%$ & \\
\hline & Research \& thesis & 4 & $11.76 \%$ & 15 & $25.86 \%$ & 19 & $20.7 \%$ & \\
\hline & Studies & 13 & $38.23 \%$ & 31 & $53.44 \%$ & 44 & $47.8 \%$ & \\
\hline & $\begin{array}{l}\text { Other } \\
\text { (communication) }\end{array}$ & 1 & $2.94 \%$ & 1 & $1.72 \%$ & 2 & & \\
\hline $\begin{array}{l}\text { Formal learning } \\
\text { on computer } \\
\text { use }\end{array}$ & Yes & 21 & $61.76 \%$ & 47 & $81.03 \%$ & 68 & $73.9 \%$ & 0.042 \\
\hline \multirow{4}{*}{$\begin{array}{l}\text { Place of } \\
\text { learning }\end{array}$} & Private classes & 16 & $47.05 \%$ & 23 & $39.65 \%$ & 40 & $42.39 \%$ & \multirow[t]{4}{*}{ NS } \\
\hline & School & 1 & $2.94 \%$ & 6 & $10.34 \%$ & 7 & $7.6 \%$ & \\
\hline & $\begin{array}{l}\text { Both private class \& } \\
\text { school }\end{array}$ & 0 & $0 \%$ & 9 & $15.51 \%$ & 9 & $9.78 \%$ & \\
\hline & Others (friends) & 3 & $8.82 \%$ & 9 & $15.51 \%$ & 12 & $13.04 \%$ & \\
\hline \multirow{3}{*}{$\begin{array}{l}\text { Time spent on } \\
\text { computers per } \\
\text { day }\end{array}$} & Less than 3hours & 24 & $70.58 \%$ & 32 & $55.17 \%$ & 56 & $60.86 \%$ & \multirow[t]{3}{*}{ NS } \\
\hline & $4-7$ hours & 7 & $20.58 \%$ & 23 & $39.65 \%$ & 30 & $32.6 \%$ & \\
\hline & Above7 hours & 3 & $8.82 \%$ & 2 & $3.44 \%$ & 5 & $5.43 \%$ & \\
\hline
\end{tabular}

${ }^{\star}$ Multiple response question

Most students use computers either at their homes or in hostels (89.13\%) (Figure 1). It was interesting to identify that even though students are provided with a computer laboratory at the University, very few used it.

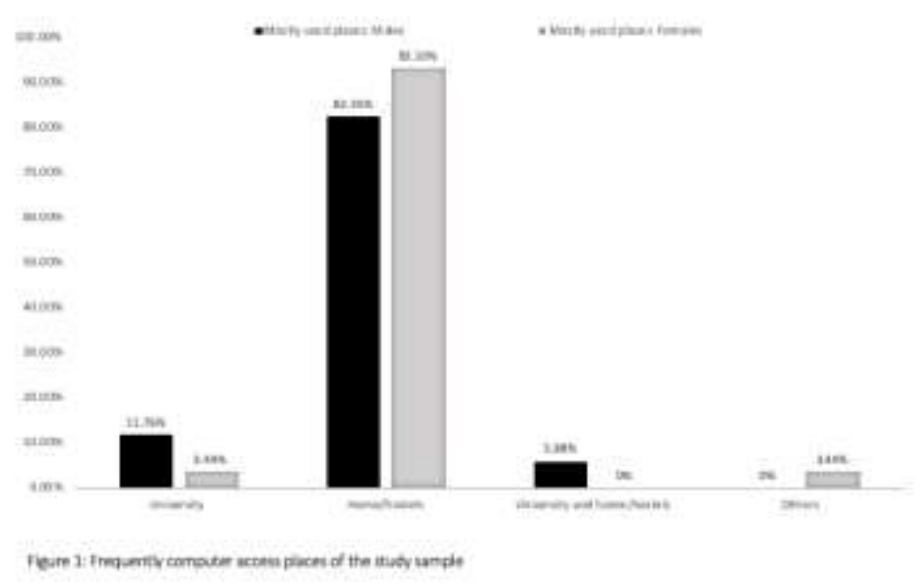

Figure 1: Frequently computer access places of the study sample

Pattern of internet use

Majority of participants had started using internet before they enrolled to the university. Out of the sample, $76.1 \% \quad(n=70)$ had used internet at home while $20.7 \% \quad(n=19)$ had accessed internet in the university. When considering the $34.9 \%$ males and $65.1 \%$ females had internet access in their homes. When considering the percentage of access to the total number of each gender, $93.1 \%$ of females and $85.29 \%$ of males had access to internet.

About Sixty eight percent students ( $n=63$ ) preferred internet over textbooks, out of which $38.1 \%$ were males and $61.9 \%$ were females. The reasons behind these preferences are outlined in Table 2 out of which 22 agreed that 
it was time saving, 37 that it had easy accessibility, 18 agreed it had latest source of information and 17 on that it had wide spectrum of information.

Majority of $89.1 \%(n=82)$ students agreed that computer and internet use should be encouraged in teaching activities, while 56.5\% $(\mathrm{n}=52)$ were satisfied with computer assisted teaching within the course and $34.78 \%(n=32)$ were not satisfied with it.

Table 2: Pattern of internet use in each gender of the study sample

\begin{tabular}{|c|c|c|c|c|c|c|c|c|}
\hline \multirow[t]{2}{*}{ Characteristics } & & \multicolumn{2}{|c|}{ Males $(n=34)$} & \multicolumn{2}{|c|}{ Females $(n=58)$} & \multicolumn{2}{|c|}{ Total } & \multirow{2}{*}{$\begin{array}{l}\text { Significance } \\
\mathbf{P}=\end{array}$} \\
\hline & & $\mathbf{N}$ & $\%$ & $\mathbf{N}$ & $\%$ & $\mathbf{N}$ & $\%$ & \\
\hline \multirow[t]{4}{*}{ Start using internet } & University & 6 & $31.6 \%$ & 13 & $68.4 \%$ & 19 & $20.65 \%$ & \multirow[t]{4}{*}{ Not tested $\#$} \\
\hline & Home & 25 & $35.7 \%$ & 45 & $64.3 \%$ & 70 & $76.08 \%$ & \\
\hline & Previous job & 2 & $100 \%$ & 0 & $0 \%$ & 2 & $2.17 \%$ & \\
\hline & Cyber café & 1 & $100 \%$ & 0 & $0 \%$ & 1 & $1.1 \%$ & \\
\hline Internet access at home & Yes & 29 & $34.9 \%$ & 54 & $65.1 \%$ & 83 & $90.21 \%$ & NS \\
\hline $\begin{array}{l}\text { Preference of internet } \\
\text { over text books }\end{array}$ & Yes & 24 & $38.1 \%$ & 39 & $61.9 \%$ & 63 & $68.47 \%$ & NS \\
\hline \multirow{5}{*}{$\begin{array}{l}\text { Reasons for internet } \\
\text { preference over using } \\
\text { text books - reasons }\end{array}$} & Time saving & 6 & $27.3 \%$ & 16 & $72.7 \%$ & 22 & $22.68 \%$ & \\
\hline & $\begin{array}{l}\text { Easy } \\
\text { accessibility }\end{array}$ & 13 & $35.1 \%$ & 24 & $64.9 \%$ & 37 & $38.14 \%$ & \\
\hline & $\begin{array}{l}\text { Latest } \\
\text { knowledge }\end{array}$ & 3 & $16.7 \%$ & 15 & $83.3 \%$ & 18 & $18.55 \%$ & \\
\hline & $\begin{array}{l}\text { Wide spectrum } \\
\text { of information }\end{array}$ & 6 & $35.3 \%$ & 11 & $64.7 \%$ & 17 & $17.52 \%$ & \\
\hline & Others & 1 & $33.2 \%$ & 2 & $66.8 \%$ & 3 & $3.09 \%$ & \\
\hline \multirow{3}{*}{$\begin{array}{l}\text { Current computer } \\
\text { assisted teaching }\end{array}$} & Satisfied & 19 & $36.5 \%$ & 33 & $63.5 \%$ & 52 & $56.52 \%$ & \multirow[t]{3}{*}{ NS } \\
\hline & Not satisfied & 11 & $34.4 \%$ & 31 & $65.6 \%$ & 32 & $34.78 \%$ & \\
\hline & Don't know & 4 & $50 \%$ & 4 & $50 \%$ & 8 & $8.69 \%$ & \\
\hline
\end{tabular}

"Multiple response question; not tested" due to small number in categories; NS - non-significant

Highest percentage (calculated as total for each gender) of both male and female participants use internet more than 8 hours per week and the values were $29.4 \%(n=10)$ and $25.9 \%$ $(n=15)$ for males and females respectively. Second highest was less than 2 hours per week and values were $9.8 \%(n=9)$ and $16.3 \%(n=15)$ for males and females. Out of male participants, $7.6 \%(n=7)$ use internet for 2 - 4 hours, $5.4 \%$ $(n=5)$ for $4-6$ hours and $3.3 \%(n=3)$ for $6-8$ hours. Out of female participants, $12 \%(n=11)$ use for $2-4$ hours, $13 \%(n=12)$ for $4-6$ hours and $5.4 \% \quad(n=5)$ for $6-8$ hours. Many participants use $1-2$ hours per week for social communication. Out of male participants, $20.7 \%(n=19)$ use for $1-2$ hours, $6.5 \%(n=6)$ for $2-3$ hours and $9.8 \%(n=9)$ above 3 hours. For female participants, values were $34.8 \%(n=32)$, $10.9 \%(n=10)$ and $15.2 \%(n=14)$ respectively. Time spent to search new information showed a similar pattern to social communication where $15.2 \%(n=14), 14.1 \%(n=13)$ and $6.5 \%(n=6)$ males spent $1-2$ hours, $2-3$ hours and more

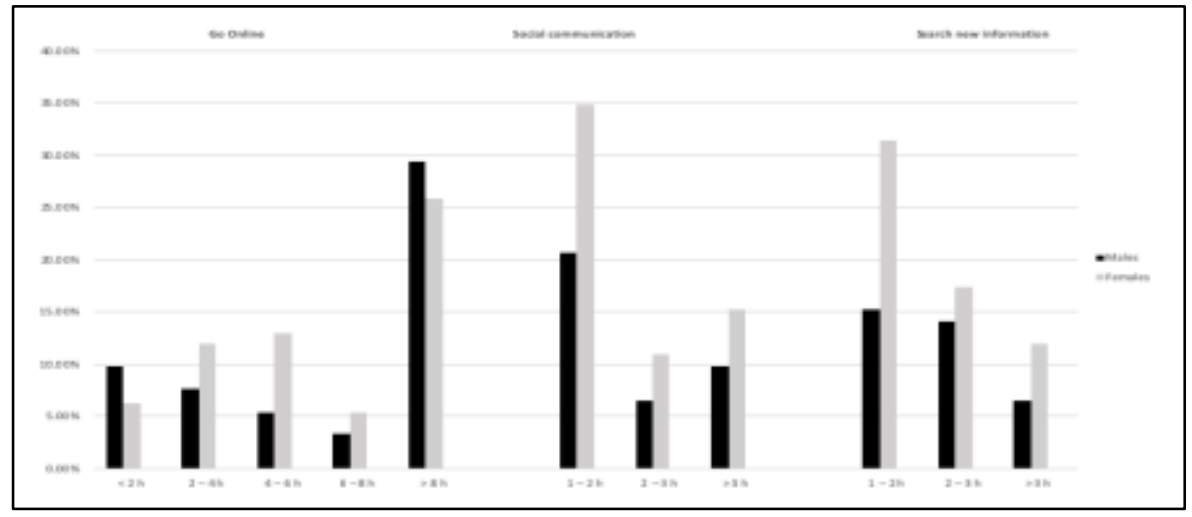

Figure 2: Time spent on internet for different purposes 
than 3 hours respectively. For females, the values were $31.5 \%(n=29), 17.4 \%(n=16)$ and $12 \%(n=11)$ for the said hours. How ever, there was no statistically significant difference in these percentages.

Purposes of internet use in each gender Under the purposes of internet use, males had highest percentage for entertainment and secondly for social communication followed by engagement in work. Females also show similar pattern of distribution. Most popular communication tool seems to be emails and instant messaging, while chat rooms also showed popularity among both genders.

Table 3: Purposes of using Internet and commonly used communication tools

\begin{tabular}{|c|c|c|c|c|c|c|c|}
\hline \multirow[t]{2}{*}{ Characters } & & Males & \multirow[t]{2}{*}{$\begin{array}{l}\text { Percentag } \\
\text { e as a total } \\
\text { from } \\
\text { gender } \\
\%\end{array}$} & \multirow[t]{2}{*}{$\begin{array}{l}\text { Females } \\
\text { N }\end{array}$} & \multirow[t]{2}{*}{$\begin{array}{l}\text { Percentag } \\
\text { e as a total } \\
\text { from } \\
\text { gender } \\
\%\end{array}$} & \multirow[t]{2}{*}{$\begin{array}{l}\text { Total } \\
\\
\mathbf{N}\end{array}$} & \multirow[t]{2}{*}{$\begin{array}{l}\text { Significance } \\
\mathbf{P}=\end{array}$} \\
\hline & & $\mathbf{N}$ & & & & & \\
\hline \multirow{5}{*}{$\begin{array}{l}\text { Reasons for } \\
\text { using Internet }\end{array}$} & Social communication & 31 & $91.17 \%$ & 50 & $86.2 \%$ & 81 & NS \\
\hline & $\begin{array}{l}\text { Engaged for work / } \\
\text { studies }\end{array}$ & 21 & $61.76 \%$ & 41 & $70.68 \%$ & 62 & NS \\
\hline & Entertainment & 32 & $94.11 \%$ & 56 & $96.55 \%$ & 88 & NS \\
\hline & $\begin{array}{l}\text { Professional } \\
\text { communication }\end{array}$ & 17 & $50 \%$ & 25 & $43.10 \%$ & 42 & NS \\
\hline & Business & 2 & $5.88 \%$ & 2 & $3.44 \%$ & 4 & NS \\
\hline \multirow{5}{*}{$\begin{array}{l}\text { Communicati } \\
\text { on tools used } \\
\text { through } \\
\text { Internet }\end{array}$} & E mail & 33 & $97.05 \%$ & 51 & $87.93 \%$ & 84 & NS \\
\hline & Instant messaging & 15 & $44.11 \%$ & 23 & $39.65 \%$ & 38 & NS \\
\hline & Web board & 3 & $8.82 \%$ & 9 & $15.51 \%$ & 12 & NS \\
\hline & Chat rooms & 17 & $50 \%$ & 29 & $50 \%$ & 46 & NS \\
\hline & News groups & 11 & $32.35 \%$ & 17 & $29.31 \%$ & 28 & NS \\
\hline
\end{tabular}

NS - non-significant

Both genders use computers for multiple reasons and no apparent pattern could be seen. Out of the purposes for using computers checked in the sample, none of the variables were significantly different in the two genders.

Time spent on Internet

Females tend to spend more time to go online than males. This difference was seen in both social communication and searching new information. Time spent more than 8 hours, $29.4 \%$ was males and $25.9 \%$ was females. Social communication is another important aspect, which is evolving in the new generation. Out of the sample, $34.8 \%$ of females and $20.7 \%$ of males spend between 1 -2hours in this purpose. Both genders spend between 1-2 hours in searching for new information, out of which $31.5 \%$ were females and $15.2 \%$ were males.

\section{Discussion}

This study was conducted in the total group of registered physiotherapy undergraduates in the University of Colombo and they represent the Sri Lankan undergraduates in health professins education. All the participants had used computers at the time of the data collection. In this sample, $95.7 \%$ had their own computer, this number was higher compared to previous studies (Lee, 2017; Munabi et al., 2015; Ranasinghe et al., 2012; Unnikrishnan, 2008). A study from Ugandan public medical schools found that $75.3 \%$ of students owned a computer (Munabi et al., 2015). A study by Ranasinghe et al., (2012) showed $77.3 \%$ owned a computer. In US adolescents, values were slightly higher compared to Uganda in which 82.1\% adolescents used computers (Lee, 2017). A study at costal South Indian medical college reported that $79 \%$ first- and second-year medical students, $38.5 \%$ final year medical students, $68 \%$ postgraduate students owned a computer. However, this variability could be due to the fact that in the recent years popularity of computers and computer assisted teaching is increasing.

In this sample, computer literacy was $100 \%$. The reason behind this high literacy might be the mandatory computer course at beginning of the programme. This finding was similar in a cross-sectional study done in Medical undergraduates in 2012 in the same Faculty, Sri Lanka (Ranasinghe et al., 2012). The authors categorized students in to low, intermediate, high and very high literacy rates and found that $47.9 \%$ were in low and intermediate level of computer literacy. In our 
study, we did not categorize literacy levels but adhered to the definition used by the Department of Census and Statistics (2018). However, literacy was lower in a study done in Nigerian medical and nursing students, where literacy was $24.1 \%$ in nursing students $58 \%$ medical students (Ajuwon, 2003) and one reason outlined by this study was that undergraduates did not have access to a computer.

Female students tend to seek more computer classes compared to male students. A study by Ranasinghe et al., (2012) found that $59.7 \%$ of students followed a formal computer course before entering to the University. In our study, percentage of students who have undergone a formal learning in either private classes, school or both were $60.86 \%$ and showed similar results to Ranasinghe et al., (2012). However, they showed there was no significant difference among genders for computer learning which was in contrast with our study finding which indicated that females showed a significant higher tendency for formal computer learning compared to males.

Considering the gender preferences, other than the formal learning of computers, none were statistically significant. Thus, computer or internet use did not differ among both genders. This finding was similar to studies by Thanuskodi, (2016); Shaw and Gant, (2002); Weiser, (2000) showing that there is no difference in use of computer or internet among different genders. Shaw and Gant (2002) suggest that males will be more comfortable with internet use compared to females. Undergraduate male and female students were introduced to five structured chat sessions and they investigated if there is a gender difference in continuing the use of internet communication tools. However, they concluded findings very similar to ours showing no difference in computer use. Weiser, (2000) concluded that previous experience in computer and internet use can produce a gender difference, however, our study participants undergo similar computer assisted learning and therefore it is possible not to observe a significance difference. Computer literacy might be one major reason why the hypothesis of gender influence in computer and internet use may not hold true.

Out of the participants, $34.9 \%$ males and $65.1 \%$ females had internet access in their homes and they used internet mainly for entertainment and secondly for social communication. This was slightly different from studies from other countries (Ajuwon, 2003; Kir et al., 2004; Li and Kirkup 2007; Maharoof et al., 2012;
Unnikrishnan et al., 2008). A study from Costal India reported most students used it for social communication such as emailing and next for entertainment. Kir et al., (2004) reported that the most common use of internet was email communication.

There were few limitations identified in our study. We used a self-administered questionnaire to identify the computer and internet use which can be very subjective. Using more objective measure such as logging time to learning management systems or measuring competencies in computer skills would give better understanding about the gender influence. Our study sample had more females thus results might be skewed towards it. Participants were in different academic years thus might have an influence on the usage time of internet and computer use.

\section{Conclusion}

There was no significant gender difference in computer and internet use in our study except for formal learning of computers. Females tend to seek more computer classes than males.

\section{Acknowledgement}

Authors would like to thank all the participants for their contribution

Conflict of interest - None

\section{References}

Ajuwon GA. (2003) Computer and internet use by first year clinical and nursing students in a Nigerian teaching hospital. BMC Medical Informatics and Decision Making. 3 (10)

Bubric K, Hedge A. (2016) Differential patterns of laptop use and associated musculoskeletal discomfort in male and female college students. Work. 55(3): 663 - 671. DOI: 10.3233/WOR162419

Department of Census and Statistics (2018) Computer literacy statistics (January - June 2018), Computer Literacy in Sri Lanka- ISSN $2012-6565$

Internet Society Global Internet Report. (2019) Open and Sustainable Access for All, Internet usage statistics, The internet big picture. World internet users and 2015 population stats 2019. 
Kir T, Ogur R, Kilic S, Tekbas OF, Hasde M. (2004) How medical students use the computer and Internet at a Turkish military medical school. Military Medical. 169(12):976-9.

Lee HH, Sung JH, Lee JY, Lee JE. (2017) Differences by Sex in Association of Mental Health With Video Gaming or Other Nonacademic Computer Use Among US Adolescents. Public Health Research, Practice and Policy. 14 (117).

Lee HY, Hwang J, Ball JG, Lee J, Yu Y, Albright DL. (2020) Mental Health Literacy Affects Mental Health Attitude: Is There a Gender Difference? American Journal of Health Behaviour. 44(3):282-291. Doi: 10.5993/AJHB.44.3.1.

Lee JW, Cho HG, Moon BY, Kim SY, Yu DS. (2019) Effects of prolonged continuous computer gaming on physical and ocular symptoms and binocular vision functions in young healthy individuals. Peer Journal. 7-7050 http://doi.org/10.7717/peerj.7050

Li N, Kirkup G. (2007) Gender and cultural differences in Internet use: A study of China and the UK 2007. Computers and Education. 48 (2).

Mao HY, Hsu HC, Lee SD. (2020) Gender differences in related influential factors of regular exercise behavior among people in Taiwan in 2007: A cross-sectional study. PLoS. 15(1). Doi: 10.1371/journal.pone.0228191.

Maroof KA, Parashar P, Bansal R. (2012) How are our medical students using the computer and internet? A study from a medical college of north India. Nigerian Medical Journal. 53 (2): 89 -93

Munabi IG, Buwembo W, Bajunirwe F, Kitara DL, Joseph R, Peter K, Obua C, Quinn J and Mwaka ES. (2015) Factors influencing health professions students' use of computers for data analysis at three Ugandan public medical schools: a cross-sectional survey. BMC Research Notes. 8 (54). DOI 10.1186/s13104015-1013-3
Ranasinghe P, Wickramasinghe SA, Pieris WAR, Karunathilake I and Constantine GR. (2012) Computer literacy among first year medical students in a developing country: A cross sectional study. BMC Research Notes. 5 (504).

Shaw LH, Gant LM. (2002) Users divided? Exploring the gender gap in internet use. Cyber Psychology and Behaviour. 5 (6). DOI: $10.1089 / 109493102321018150$

Singh PK, Jasilionis D, Oksuzyan A. (2018) Gender difference in cognitive health among older Indian adults: A cross-sectional multilevel analysis. SSM Population Health.180-187. Doi: 10.1016/j.ssmph.2018.06.008.

Statistical Reports, Sri Lanka University statistics 2018, University grant commission. ISSN : 2279 $-2104$

https://www.ugc.ac.lk/en/statistical-reports/2131-srilanka-university-statistics-2018.html

Thanuskodi S. (2016) Gender Differences in Internet Usage among College Students: A Comparative Study. Library Philosophy and Practice (ejournal) Library Philosophy and Practice 1052. https://digitalcommons.unl.edu/libphilprac/1052

Unnikrishnan B, Kulshrestha V, Saraf A, Agrahari A C, Prakash S, Samantaray L, Parida A (2008). Pattern of computer and internet use among medical students in Coastal South India. South East Asian Journal of Medical Education. 2 (2)

Weiser EB. (2000) Gender Differences in Internet Use Patterns and Internet Application Preferences: A Two-Sample Comparison. Cyber Psychology \& Behavior. 3(2): 167-178.

Wan CS, Chiou WB. (2006) Why Are Adolescents Addicted to Online Gaming? An Interview Study in Taiwan. Cyber psychology and behavior. 9 (6). 